\title{
AMAR
}

AMAR (Andalas Management Review)

Vol.4, No. 2 (2020) 1-15

The Management Institute, Faculty of Economics, Universitas Andalas

ISSN (Print) 2476-9282 | ISSN (Online) 2548-155X

\section{Pengaruh Kualitas Produk dan Kualitas Layanan terhadap Keputusan Konsumen Corporate dalam Menggunakan TV Berlangganan MNC Vision di Kota Palembang}

\author{
M. Fitriansyah Eka Putra a Zakaria Wahab b, Muchsin Saggaff Shihab c,Marlina Widiyantid \\ aProgram Studi Magister Manajemen Universitas Sriwijaya, rian.erida@gmail.com \\ bProgram Studi Magister Manajemen Universitas Sriwijaya, zkwahab01@gmail.com \\ cProgram Studi Magister Manajemen Universitas Sriwijaya, muchsin.shihab@bakrie.ac.id \\ dProgram Studi Magister Manajemen Universitas Sriwijaya,marlinawidiyanti68@yahoo.co.id
}

\begin{abstract}
Penelitian ini dilakukan bertujuan untuk mengetahui pengaruh kualitas produk dan kualitas layanan terhadap keputusan konsumen corporate dalam menggunakan tv berlangganan MNC Vision di kota Palembang. Populasi dalam penelitian ini adalah seluruh pelanggan corporate aktif MNC Vision di kota Palembang tahun 2020 sebanyak 37 pelanggan. Sampel yang digunakan dalam penelitian ini adalah sebanyak 100 responden dengan menggunakan teknik purposive sampling. Metode pengumpulan data menggunakan kuesioner dan teknik pengolahan data menggunakan analisis regresi linier berganda. Hasil dari analisis menunjukkan bahwa kualitas produk berpengaruh positif dan signifikan terhadap keputusan konsumen corporate dalam menggunakan to berlangganan MNC Vision di kota Palembang. Kualitas layanan berpengaruh positif dan signifikan terhadap keputusan konsumen corporate dalam menggunakan to berlangganan MNC Vision di kota Palembang. Kualitas produk pada MNC Vision diharapkan dapat menampilkan channel-channel khusus atau channel yang berbeda dari provider TV berlangganan lain. Kualitas layanan dapat memberikan perhatian apabila terjadi gangguan atau trouble dengan memberikan respon yang cepat dan tanggap.
\end{abstract}

Keyword: Kualitas Produk, Kualitas Layanan, Keputusan Konsumen

\section{PENDAHULUAN}

TV berlangganan merupakan sebuah jasa penyiaran saluran televisi yang dilakukan khusus untuk pemirsa yang bersedia membayar perusahaan (berlangganan) secara berkala. Jasa ini biasanya disediakan dengan menggunakan sistem digital ataupun analog melalui media satelit dan kabel. Konfigurasinya pun cukup sederhana, yakni perangkat TV seperti antenna parabola, decorder/receiver, dan LNB (low noise block) yang telah di setting untuk dapat menangkap sinyal yang di pancarkan oleh satelit. Saat ini sudah banyak sekali provider TV berlangganan di Indonesia menggunakan media satelit.

MNC Vision merupakan pelopor di dunia industri TV berlangganan di Indonesia yang dimulai sejak tahun 1994 dengan menggunakan layanan DTH (direct to home) yaitu sebuah 
layanan yang memberikan pilihan 137 saluran terbaik dengan 32 channel eksklusif yang dihadirkan langsung ke TV di rumah pribadi pelanggan. Dengan penetrasi pasar yang mencapai lebih dari 70\% menjadikan MNC Vision sebagai operator terbesar DTH di Indonesia saat ini. MNC Vision merupakan transformasi dari 3 nama dagang sebelumnya yaitu Indovision, Okevision, dan Top TV, dengan mengusung nama dan desain yang baru MNC Vision berharap dapat memberikan layanan yang lebih inovatif, modern, dan sesuai dengan perkembangan teknologi dan kebutuhan pasar saat ini. Menggunakan satelit frekuensi S-Band yang memiliki keunggulan berupa daya tahan cuaca yang tinggi, tayangan MNC Vision sangat cocok digunakan daerah tropis seperti Indonesia (www.mncvision.id, 2017).

Pada tahun 2004 MNC Vision juga membentuk divisi corporate comsales yang bertujuan untuk menjangkau pelanggan-pelanggan corporate/komersial seperti hotel, rumah sakit, apartemen, perusahaan lepas pantai, dan real estate yang membutuhkan layanan TV berlangganan MNC Vision. Perbedaan mendasar lain nya yang membedakan layanan DTH (direct to home) dan corporate comsales terdapat pada teknologi konfigurasi SMATV (satellite master antenna television) yang hanya menggunakan dua parabola untuk menangkap sinyal dari satelit lalu diteruskan menggunakan kabel jaringan coxial ke ruang server yang terdiri dari modulator dan decoder yang disusun sedemikian rupa, lalu menyalurkan tayangan ke titik-titik TV yang membutuhkan siaran, sistem SMATV ini dapat mendukung kurang lebih 200-300 titik TV dalam satu waktu (www.mncvision.id, 2017).

Pada saat ini provider-provider TV berlangganan tidak hanya menyediakan jasa berupa channel-channel eksklusif saja tetapi juga sudah menerapkan berbagai macam teknologi seperti, teknologi jaringan internet dan jaringan $4 \mathrm{G}$ guna menggaet pelanggan dan secara langsung menjadi kompetitor baru bagi MNC Vision, dengan keadaan seperti ini dimana provider pesaing TV berlangganan semakin banyak dan teknologi yang digunakan pun semakin canggih tentunya membuat MNC Vision tertantang untuk terus bereksplorasi dalam meningkatkan kualitas produk dan kualitas layanannya. Menurut (Kotler \& Keller, 2009) pelayanan merupakan fitur dan karakteristik produk dan jasa yang bergantung pada kemampuanya untuk memenuhi kebutuhan yang dinyatakan atau tersirat.

MNC Vision memiliki beberapa kantor cabang pembantu di kota-kota besar salah satu nya di kota Palembang, yaitu MNC Vision Palembang. Mewujudkan visi dan misi perusahaan, divisi corporate comsales MNC Vision Palembang berkomitmen tetap eksis dalam memenuhi kebutuhan para pelanggan dikhususkan pada Wilayah Palembang. Adanya pengalaman selama 26 tahun dalam bisnis TV Berlangganan, perseroan meyakinkan adanya 
MNC Vision di kota Palembang mampu menjawab kebutuhan konsumen masyarakat kota Palembang tidak hanya dalam menyajikan tayang yang berkualitas, dalam hal memberikan tayangang edukatif, informatif dan menghibur yang lebih baik dan bermutu untuk masyarakat kota Palembang.

Tabel 1.

Data Pelanggan Corporate MNC Vision Kota Palembang (Aktif)

\begin{tabular}{ccccc}
\hline \multirow{2}{*}{ Tahun } & \multicolumn{4}{c}{ Pelanggan Corporate } \\
\cline { 2 - 5 } & $\begin{array}{c}\text { Jumlah } \\
\text { Pelanggan }\end{array}$ & $\begin{array}{c}\text { Percentage } \\
\text { Pelanggan } \\
(\%)\end{array}$ & $\begin{array}{c}\text { Revenue } \\
\text { Sales } \\
(\text { Rp/Bulan) }\end{array}$ & $\begin{array}{c}\text { Percentage } \\
\text { Revenue } \\
(\%)\end{array}$ \\
\hline 2016 & 7 & - & 34.470 .000 & - \\
2017 & 8 & $(+) 14,28$ & 52.193 .156 & $(+) 51,41$ \\
2018 & 12 & $(+) 50$ & 63.585 .300 & $(+) 21,82$ \\
2019 & 5 & $(-) 58,33$ & 32.200 .000 & $(-) 49,35$ \\
\hline
\end{tabular}

Sumber Data: MNC Vision Cabang Kota Palembang

Pada Tabel 1 dapat dilihat peningkatan jumlah pelanggan corporate yang aktif di MNC Vision Cabang kota Palembang sejak tahun 2016- 2019. Data diatas terlihat adanya kenaikan jumlah pelanggan MNC Vision menggalami peningkatan pada tahun 2017 sebesar 14,28\% dan sisi revenue sales naik sekitar 51,41\% dari tahun sebelumnya. Pada tahun 2018 kenaikan dari sisi pelanggan kembali meningkat sebesar $50 \%$ dan $21,82 \%$ untuk revenue sales. Kemudian menggalami penurunan pada tahun 2019 yaitu sebesar 58,33\% dan penurunan revenue sales sebesar 49,35\% yang dikarenakan semakin sulit persaingan bisnis TV berlangganan di kota Palembang.

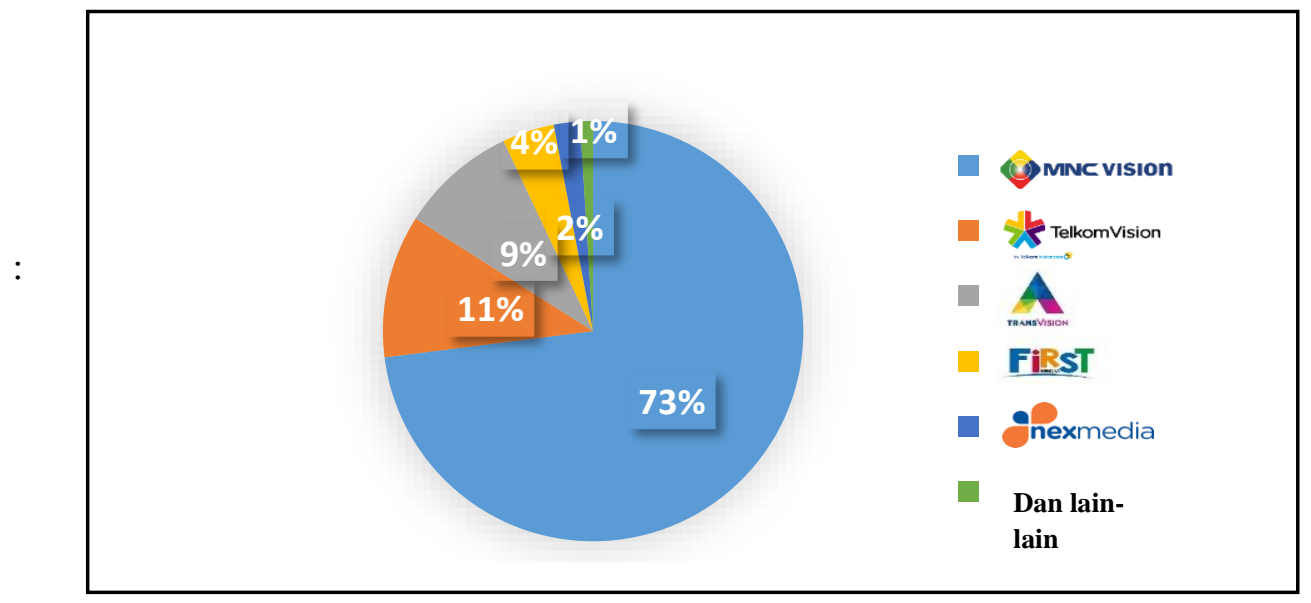

Gambar 1. Data Market Share TV Berlangganan di Indonesia 


\section{Sumber Data: MNC Vision Cabang Kota Palembang}

Pada Gambar 1 dapat dilihat bahwa MNC Vision merupakan pemilik market share TV berlangganan terbesar di Indonesia yang disusul oleh provider TV berlangganan seperti TelkomVision, TransVision, First Media, Nex Media, dan lain-lain. Dengan adanya providerprovider TV berlangganan yang masih memiliki porsi market yang masih sedikit tentunya membuat persaingan di bidang bisnis tersebut semakin ketat dan masing-masing provider pastilah memiliki keunggulan pada produk dan layanan yang mereka tawarkan. Di sisi lain dapat menjadi keuntungan tersendiri bagi konsumen, karena dengan banyaknya ragam pilihan produk yang diberikan konsumen bisa memilih layanan dan paket hiburan TV yang sesuai dengan kebutuhan dan keinginan mereka.

Tabel 1.

Produk TV Berlangganan yang Ditawarkan MNC Vision Divisi

\begin{tabular}{|c|c|c|c|c|c|c|c|c|}
\hline & \multicolumn{2}{|c|}{ Channel Only } & \multicolumn{6}{|c|}{ Head End } \\
\hline & \multirow[b]{2}{*}{$\begin{array}{c}\text { Decod } \\
\text { er }\end{array}$} & \multirow[b]{2}{*}{$\begin{array}{c}\text { Cam } \\
\text { Modu } \\
\text { le }\end{array}$} & \multicolumn{3}{|c|}{ Digital } & \multicolumn{3}{|c|}{ Transmodulator } \\
\hline & & & $\begin{array}{c}\text { Hotel } * 3 \\
\text { Hospital } \\
\text { Entertai } \\
\text { ment }\end{array}$ & $\begin{array}{c}\text { Hotel } \\
* 4 \\
\text { Apartm } \\
\text { ent }\end{array}$ & $\begin{array}{c}\text { Hotel } \\
* 5 \\
\text { Oil } \\
\text { Minin } \\
\text { g }\end{array}$ & $\begin{array}{c}\text { Hotel *3 } \\
\text { Hospital } \\
\text { Entertai } \\
\text { ment }\end{array}$ & $\begin{array}{c}\text { Hotel } \\
* 4 \\
\text { Apartm } \\
\text { ent }\end{array}$ & $\begin{array}{c}\text { Hotel } \\
* 5 \\
\text { Oil } \\
\text { Minin } \\
\text { g }\end{array}$ \\
\hline Unit Charge & \multicolumn{2}{|c|}{$15 \%$} & \multicolumn{3}{|c|}{$15 \%$} & \multicolumn{3}{|c|}{$20 \%$} \\
\hline Opex (IDR) & \multicolumn{2}{|c|}{460} & 460 & 720 & 1690 & 460 & 720 & 1690 \\
\hline $\begin{array}{c}\text { Harga } \\
\text { Equipment }\end{array}$ & \multicolumn{2}{|c|}{ Normal } & \multicolumn{3}{|c|}{ Normal } & \multicolumn{3}{|c|}{ Normal } \\
\hline
\end{tabular}

Sumber Data: MNC Vision Cabang Kota Palembang

Pada Tabel 2, produk berlangganan yang ditawarkan diatas dapat dilihat bahwa MNC Vision di divisi corporate comsales memberikan variasi penawaran berupa paket channel only (paket yang hanya memberikan layananan channel saja dengan support alat sebatas decoder atau cam module) dan head end (paket yang memberikan layananan dengan 2 macam modulator, yaitu digital dan transmodulator dengan support alat lengkap dari MNC Vision di bagian server). Pada unit charge dapat dilihat bahwa MNC Vision hanya men-charge 15\% saja untuk total kamar pada tiap properti. Opex (operational expenses) akan ditentukan berdasarkan tingkat rate tiap properti atau hotel (Bintang 3, Bintang 4, dan Bintang 5) memiliki opex yang 
berbeda-beda dan harga alat/ equipment yang dipasang menyesuaikan dengan kebutuhan properti masing-masing.

Tabel 2.

Pelayanan yang Diberikan MNC Vision Kota Palembang

\begin{tabular}{|c|c|c|}
\hline No. & After Sales Service & Keterangan \\
\hline 1. & $\begin{array}{l}\text { SLA (Sales Level } \\
\text { Agreement) }\end{array}$ & $\begin{array}{l}\text { Pelayanan berupa bentuk SLA (service level } \\
\text { agreement) dalam hal trouble/ masalah tayangan } \\
\text { TV dengan support tim teknisi khusus. }\end{array}$ \\
\hline 2. & Preventive Maintenance & $\begin{array}{l}\text { Pelayanan yang diberikan per } 3 \text { bulan sekali } \\
\text { selama masa kontrak berlangsung. }\end{array}$ \\
\hline 3. & One Billing System Invoice & Metode pembayaran One Billing System. \\
\hline 4. & Free Trial & Masa percobaan gratis selama 1 bulan. \\
\hline 5. & Free Channel & $\begin{array}{l}\text { Bebas memilih channel lokal dan luar apa saja } \\
\text { sesuai keinginan pelanggan. *(terbatas pada } \\
\text { channel-channel yang bekerjasama dengan MNC } \\
\text { Sky Vision). }\end{array}$ \\
\hline
\end{tabular}

Sumber: MNC Vision Cabang Kota Palembang

Data pada Tabel 3, dapat dilihat bahwa pelanggan corporate MNC Vision dibebaskan untuk memilih channel-channel eksklusif apa saja yang ingin ditayangkan pada properti mereka dan akan mendapatkan pelayanan berupa SLA (service level agreement) dalam hal trouble/ masalah tayangan TV dengan support tim teknisi khusus yang akan datang dalam $1 \mathrm{x}$ 5 jam (kota Palembang) dan 1 × 24 jam (luar kota Palembang). Preventive maintence selama kontrak berlangsung yaitu perawatan yang dilakukan per 3 bulan sekali utnuk alat-alat yg di support oleh tim teknisi MNC seperti parabola, modulator, decoder, LNB (low noise block) dan kabel. Metode pembayaran dilakukan dengan cara one billing system yaitu pembayaran dimuka dengan sistem 1 invoice perbulan untuk satu property. Adanya masa free trial selama 1 bulan untuk melihat kualitas tayangan dan alat-alat yang digunakan.

\subsection{Keputusan Pembelian}

Keputusan pembelian adalah suatu tahap dimana konsumen telah memiliki pilihan dan siap untuk melakukan pembelian atau pertukaran antara uang dan janji untuk membayar dengan hak kepemilikan atau penggunaan suatu barang atau jasa (Kotler \& Keller, 2016).

\subsection{Kualitas Produk}

Kualitas produk (product quality) merupakan kemampuan sebuah produk dalam memperagakan fungsinya dan merupakan salah satu faktor yang paling diandalkan oleh 
seorang pemasar dalam memasarkan suatu produk (Kotler \& Armstrong, 2015). Kualitas produk yang dianggap baik oleh konsumen akan menciptakan keputusan pembelian. keputusan pembelian akan dilakukan ketika konsumen sudah memilih produk yang cocok untuk memenuhi kebutuhannya (Monalisa, Suharyono, \& Sunarti, 2015).

\subsection{Kualitas Pelayanan}

Kualitas pelayanan (service quality) merupakan penilaian pelanggan atas keunggulan atau keistimewaan suatu produk atau layanan secara menyeluruh (Parasuraman et al., 1990). Salah satu model kualitas layanan yang banyak dijadikan acuan dalam riset pemasaran adalah model service quality. Sevice quality dibangun atas adanya perbandingan dua faktor utama yaitu persepsi pelanggan atas pelayanan yang nyata mereka terima dengan pelayanan yang sesungguhnya diharapkan dan diinginkan.

\section{METODE}

\subsection{Jenis Penelitian}

Penelitian ini bersifat penelitian kausal. Hal ini dikarenakan penelitian ini bertujuan untuk meneliti hubungan sebab-akibat antara variabel independen kualitas produk dan kualitas layanan dan variabel dependen keputusan konsumen corporate dalam memilih jasa TV berlangganan MNC Vision Palembang tahun 2020.

\subsection{Teknik Pengumpulan Data}

Teknik penentuan sampel dalam penelitian ini menggunakan teknik purposive sampling. Dengan pertimbangan untuk mengemat waktu, tenaga dan mendapatkan hasil yang lebih akurat, maka jumlah sampel yang digunakan dalam penelitian ini sebanyak 100 responden yang dibagikan melalui menyebarkan kuesioner kepada seluruh pelanggan corporate aktif MNC Vision di kota Palembang.

\subsection{Populasi dan Sampel}

Populasi dalam penelitian ini adalah seluruh pelanggan corporate aktif MNC Vision di kota Palembang tahun 2020 sebanyak 37 pelanggan corporate. Penentuan besarnya sampel diperoleh dari ukuran sampel yaitu lebih besar dari 30 responden dan kurang dari 500 responden (Rescoe, 2006).

\subsection{Teknik Analisis Data}

Metode yang digunakan dalam penelitian ini adalah analisis regresi linier berganda. Metode ini berguna untuk mengetahui pengaruh hubungan secara langsung antara dua 
variabel atau lebih variabel bebas dengan satu variabel terikat maka digunakan teknik analisis regresi linier berganda. Dalam penelitian ini adalah antara variabel independen kualitas produk dan kualitas layanan serta variabel dependen keputusan konsumen corporate dalam memilih jasa TV berlangganan MNC Vision Palembang tahun 2020.

\section{HASIL DAN PEMBAHASAN}

\subsection{Hasil Analisis Regresi Linier Berganda}

Analisis regresi linier berganda dilakukan untuk mengetahui pengaruh variabel kualitas produk (X1) dan kualitas layanan (X2) terhadap keputusan konsumen (Y). Berdasarkan hasil pengujian diperoleh sebagai berikut:

Tabel 4.

Hasil Analisis Regresi Linier Berganda

\begin{tabular}{clcccc}
\hline \multirow{2}{*}{ Model } & & \multicolumn{3}{c}{ Coefficients } \\
& \multicolumn{2}{c}{$\begin{array}{c}\text { Unstandardized } \\
\text { Coefficients }\end{array}$} & $\begin{array}{c}\text { Standardized } \\
\text { Coefficients }\end{array}$ & \\
\hline \multirow{2}{*}{$\mathbf{1}$} & & $\mathrm{B}$ & Std. & Beta & Sig \\
& & & Error & & \\
\hline \multirow{2}{*}{ Constant } & .105 & .246 & & \\
& Kualitas Produk & .671 & .078 & .672 & .000 \\
& Kualitas Layanan & .192 & .078 & .193 & .016 \\
\hline
\end{tabular}

Sumber Data: Diolah dari Kuesioner, 2020

Berdasarkan pada Tabel 4 tersebut, hasil analisis regresi linier berganda dapat dinyatakan dengan persamaan sebagai berikut:

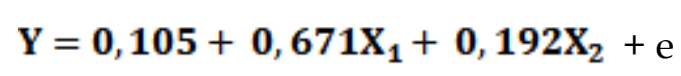

Persamaan regresi linier di atas dapat dijelaskan sebagai berikut:

a. Nilai konstanta menunjukkan nilai positif dengan nilai sebesar 0,105. Hal ini menunjukkan bahwa keputusan konsumen dalam menggunakan TV berlangganan MNC Vision dianggap bahwa dengan tanpa adanya pengaruh dari kualitas produk dan kualitas layanan, maka besarnya variabel keputusan konsumen sebesar 0,105.

b. Nilai koefisien regresi variabel kualitas produk sebesar 0,671 dengan nilai thitung $_{\text {sebesar }}$ 8,563 menyatakan bahwa kualitas produk berpengaruh positif terhadap keputusan konsumen. Hal ini menunjukkan bahwa semakin tinggi kualitas produk, maka akan 
berdampak positif yaitu semakin tinggi keputusan konsumen menggunakan TV berlangganan MNC Vision.

c. Nilai koefisien regresi variabel kualitas layanan sebesar 0,192 dengan nilai $t_{\text {hitung }}$ sebesar 2.455 menyatakan bahwa kualitas layanan berpengaruh positif terhadap keputusan konsumen. Hal ini menunjukkan bahwa semakin tinggi kualitas layanan yang diberikan, maka akan berdampak positif yaitu semakin tinggi keputusan konsumen menggunakan TV berlangganan MNC Vision.

\subsection{Hasil Uji Koefisien Korelasi (r) dan Koefisien Determinasi $\left(\mathbf{R}^{2}\right)$}

Tabel 5.

Hasil Uji Koefisien Korelasi (r) dan Koefisien Determinasi $\left(\mathbf{R}^{2}\right)$

Model Summary ${ }^{\text {b }}$

\begin{tabular}{cccrr}
\hline Model & R & R Square & $\begin{array}{c}\text { Adjusted } \mathbf{R} \\
\text { Square }\end{array}$ & \multicolumn{2}{c}{$\begin{array}{c}\text { Std. Error of the } \\
\text { Estimate }\end{array}$} \\
\hline 1 & .810 & .657 & .650 & .575889
\end{tabular}

Sumber Data: Diolah dari Kuesioner, 2020

Berdasarkan output model summary pada Tabel 5 hasil uji koefisien korelasi (r) terlihat bahwa besarnya pengaruh variabel kualitas produk dan kualitas layanan terhadap keputusan konsumen yaitu sebesar 0,810 atau sebesar $81,0 \%$. Besarnya angka $R$ square $\left(R^{2}\right)$ adalah 0,657 atau sebesar $65,7 \%$, angka tersebut digunakan untuk melihat bagaimana kualitas produk dan kualitas layanan berpengaruh terhadap keputusan konsumen corporate dalam menggunakan TV berlangganan MNC Vision.

Angka tersebut mempunyai maksud bahwa bagaimana variabel kualitas produk dan kualitas layanan dalam menunjukkan faktor apa saja yang dapat mempengaruhi keputusan konsumen corporate dalam menggunakan TV berlangganan MNC Vision dan secara bersamasama sebesar $65,7 \%$ sedangkan sisanya 34,3\% dipengaruhi oleh faktor-faktor lain seperti citra perusahaan, promosi, harga dan lainnya.

\subsection{Hasil Uji Signifikansi Parameter Individual (Uji t)}

Uji signifikansi parameter individual (uji t) bertujuan untuk mengetahui seberapa jauh pengaruh variabel bebassecara individual terhadap variabel terikat.Penelitian ini dengan signifikansi $5 \%$ atau $a=0,05$. Hasil uji t dapat dilihat pada Tabel 4.11 sebagai berikut:

Tabel 6.

\section{Hasil Uji Signifikansi Parameter Individual (Uji t)}




\begin{tabular}{|c|c|c|c|c|c|}
\hline \multicolumn{6}{|c|}{ Coefficients } \\
\hline Model & Variabel & B & $t_{\text {tabel }}$ & $\mathbf{t}_{\text {hitung }}$ & Sig. \\
\hline \multirow[t]{2}{*}{1} & Kualitas Produk & .671 & 1.660 & 8.563 & .000 \\
\hline & Kualitas Layanan & .192 & 1.660 & 2.455 & .016 \\
\hline
\end{tabular}

Sumber Data: Diolah dari Kuesioner, 2020

Berdasarkan pada Tabel 6, nilai degree of freedom (df) $=\mathrm{n}-\mathrm{k}=100-3=97$ dan 0,05 maka diperoleh nilai $\mathrm{t}_{\text {tabel }}$ untuk data penelitian ini adalah 1,660. Hasil analisis dapat dijelaskan sebagai berikut:

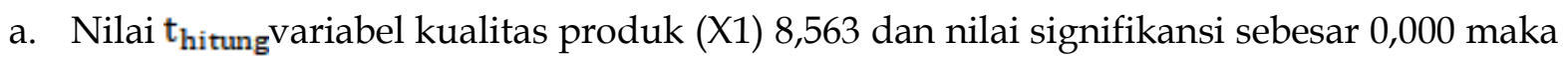
nilai $t_{\text {hitung }}>t_{\text {tabelyaitu }}(8,563>1,660)$ atau nilai (Sig.) $0,000<0,05$. Artinya kualitas produk berpengaruh signifikan terhadap keputusan konsumen corporate menggunakan TV berlangganan MNC Vision. Hal ini membuktikan bahwa hipotesis pertama pada variabel kualitas produk berpengaruh positif dan signifikan dapat diterima.

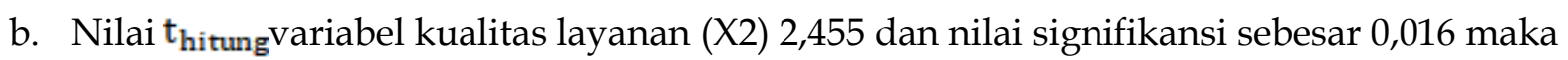
nilai $t_{\text {hitung }}>t_{\text {tabelyaitu }}(2,455>1,984)$ atau nilai (Sig.) $0,016<0,05$. Artinya kualitas layanan berpengaruh signifikan terhadap keputusan konsumen corporate dalam menggunakan TV berlangganan MNC Vision. Hal ini membuktikan bahwa hipotesis kedua pada variabel kualitas layanan berpengaruh positif dan signifikan dapat diterima.

\subsection{Pembahasan}

Berdasarkan hasil penelitian diatas maka diperoleh pembahasan sebagai berikut:

a. Kualitas Produk. Kualitas produk berpengaruh positif dan signifikan terhadap keputusan konsumen. Hasil penelitian ini sejalan dengan hasil penelitian dari (Wicaksana, 2018); (Hendro \& Hidayat, 2018); (Pratama \& Santoso, 2018); (Pratiwi et al., 2018); (Rafi \& Budiatmo, 2018); (Sumpu \& Tumbel, 2018); (Sulistyorini, 2018); (Alim et al., 2018); (S \& Suryoko, 2017); (Aryaty \& Budiatmo, 2017); (Supriyadi et al., 2016); (Fure et al., 2015); (Dharma \& Sukaatmadja, 2015); (Mahmudah \& Tiarawati, 2014); (Ratnasari et al., 2014); (Fatalah, 2013) menunjukkan hasil yang sama yaitu variabel kualitas produk berpengaruh positif dan signifikan terhadap keputusan pembelian. Kualitas produk sangat diperhatikan oleh konsumen. Konsumen menginginkan kualitas produk yang terbaik pada produk-produk yang telah di beli.Kualitas produk merupakan salah satu kunci persaingan diantara pelaku usaha yang ditawarkan 
kepada konsumen. Kualitas juga sangat berdampak pada kinerja produk atau jasa, oleh sebab itu kualitas memiliki hubungan yang erat dengan keputusan konsumen. Kualitas produk yang baik akan mendorong konsumen melakukan pembelian (Harjuno, 2018). Pada perkembangan kondisi pasar atas produk yang dipasarkan, perusahaan perlu melakukan variasi produk yang lebih update jika dibandingkan dengan kompetitor sejenisnya. Hal tersebut sangat penting dan memiliki hubungan dalam pandangan konsumen untuk melakukan keputusan dalam membeli suatu produk atau jasa (Putri, 2017). Kualitas produk yang dianggap baik oleh konsumen akan menciptakan keputusan pembelian. Keputusan pembelian ini akan dilakukan ketika konsumen sudah dapat memilih produk apa yang cocok untuk memenuhi kebutuhannya(Monalisa et al., 2015). Hasil penelitian ini menunjukkan bahwa kualitas produk yang ditawarkan TV berlangganan MNC Vision yang dihubungkan dengan beberapa indikator seperti kinerja (performance), tampilan (features), keandalan (reliability) dan daya tahan (durability). Pada indikator kinerja (performance) menunjukkan skor rata-rata tertinggi terhadap keputusan konsumen. TV berlangganan MNC Vision memberikan kualitas visual yang berkualitas baik. Dengan tetap menjaga rasa puas pengguna terhadap produk yang ditawarkan, perlu untuk tetap dipertahankan dan ditingkatkan lagi dalam memberikan kualitas TV berlangganan agar tetap dapat bersaing dengan kompetitor sejenisnya. Kondisi ini ditunjukkan dari item "kualitas visual dan audio TV berlangganan MNC Vision berkualitas baik" yang mempunyai nilai tertinggi, dimana menunjukkan bahwa konsumen merasa tertarik untuk memutuskan menggunakan TV berlangganan MNC Vision. Pada indikator “TV berlangganan MNC Vision menghadirkan channel-channel pilihan yang tidak dimiliki provider TV berlangganan yang lain" perlu mendapatkan perbaikan, sebab menurut calon pelanggan, indikator ini menunjukkan nilai rata-rata terkecil sehingga perlu adanya evaluasi dan peningkatan. Peningkatan yang perlu dilakukan yaitu dalam menawarkan channel-channel yang lebih lengkap dan jenis paket tv yang menarik dari kompetitor sejenisnya. Peningkatan ini juga perlu disesuaikan dengan beberapa kalangan dengan beberapa jenis kebutuhan untuk memberikan rasa tertarik bagi calon konsumen untuk menggunakan TV berlangganan MNC Vision.

b. Kualitas Layanan. Kualitas layanan berpengaruh positif dan signifikan terhadap keputusan konsumen. Hasil ini sejalan dengan hasil penelitian dari (Adyanto \& Santosa, 2018a); (Febriani, 2018); (Faruq, 2018); (Adyanto \& Santosa, 2018a); (Tugiso et 
al., 2016); (Jundi, 2016); (Isyanahapsari, 2016)yang menunjukkan hasil bahwa variabel kualitas pelayanan berpengaruh positif dan signifikan terhadap keputusan pembelian. Faktor kedua yang mempengaruhi keputusan pembelian adalah kualitas layanan. Adanya kualitas layanan yang baik, maka konsumen akan memperoleh barang atau jasa untuk memenuhi kebutuhannya. Kualitas layanan yang baik menjadi hal yang sangat penting dalam dunia usaha. Kualitas layanan yang diberikan perusahaan yaitu bertujuan untuk memberikan kemudahan bagi konsumen. Setiap menjalankan bisnis baik barang atau jasa, konsumen harus diberikan layanan yang baik karena kualitas pelayanan memiliki hubungan yang erat dengan keputusan konsumen dalam melakukan pembelian. perusahaan dapat mempertahankan usahanya dan mampu bersaing dengan pesaing lainnya apabila memberikan pelayanan yang baik(Permatasari, 2017). Kualitas pelayanan memiliki peranan yang penting dalam memberikan nilai tambah terhadap pengalaman service secara keseluruhan. Sama halnya seperti kualitas produk, seorang konsumen akan mengevaluasi kualitas layanan berdasarkan persepsi. Maka dengan ini, MNC Vision perlu melakukan strategi dan program layanan, karena hal ini sangat penting agar konsumen tidak mengurungkan niatnya ketika akan melakukan keputusan pembelian (Kusumah, 2016).

Kualitas layanan yang diberikan dihubungkan dengan dimensi bukti fisik (tangible), empati (emphaty), daya tanggap (responsiveness), dan jaminan (assurance). Berdasarkan hasil penelitian menunjukkan bahwa pada dimensi jaminan (assurance) menunjukkan nilai skor rata-rata tertinggi terhadap keputusan konsumen. Kualitas pelayanan yang mempengaruhi keputusan konsumen dapat diartikan sebagai pemenuhan kebutuhan dan keinginan konsumen serta ketepatan penyampaiannya dalam mengimbangi harapan konsumen. Kondisi ini ditunjukkan pada item pertanyaan "MNC Vision memberikan jaminan gambar tayangan dalam keadaan baik selama masa kontrak" yang mempunyai nilai rata-rata skor tertinggi, dimana menunjukkan bahwa konsumen tertarik untuk melakukan pembelian dengan adanya jaminan yang diberikan MNC Vision dalam menawarkan produknya kepada konsumen. Pada indikator "kualitas layanan yang diberikan TV berlangganan MNC Vision yang memberikan layanan preventive maintenance berupa kunjungan tim teknisi minimal 3 bulan sekali untuk pengecekan alat", perlu mendapatkan penyesuaian, perbaikan dan peningkatan sebab menurut pelanggan indikator ini menunjukkan skor rata-rata dengan nilai terkecil. 


\section{KESIMPULAN DAN IMPLIKASI}

\subsection{Kesimpulan}

Berdasarkan hasil penelitian dan analisis yang telah dilakukan, maka dapat diambil kesimpulan sebagai berikut:

a. Kualitas produk berpangaruh positif dan signifikan terhadap keputusan konsumen corporate dalam menggunakan TV berlangganan MNC Vision di kota Palembang.

b. Kualitas layanan berpangaruh positif dan signifikan terhadap keputusan konsumen corporate dalam menggunakan TV berlangganan MNC Vision di kota Palembang.

\subsection{Impilikasi}

Berdasarkan hasil penelitian, pembahasan, dan kesimpulan diatas, dapat diajukan beberapa saran agar mendapatkan hasil yang lebih baik sebagai berikut:

a. Bagi MNC Vision kota Palembang

1) Pada variabel kualitas produk, MNC Vision diharapkan tetap menampilkan channel-channel khusus atau channel yang berbeda dari provider TV berlangganan lain. Seharusnya MNC Vision juga menghadirkan channel yang eksklusif dan favorit kepada pelanggan corporate yaitu channel yang tidak dimiliki oleh provider TV berlangganan lain. MNC Vision juga diharapakan dapat menjamin seluruh disribusi jaringan kabel property yang selama ini menajadi salah satu kendala dalam keputusan pelanggan untuk menggunakan TV berlangganan MNC Vision tanpa mengenakan biaya tambahan.Hal-hal diatas jika dilakukantentunya dapat meningkatkan keputusan konsumen dalam menggunakan TV berlangganan MNC Vision.

2) Pada variabel kualitas layanan, seharusnya MNC Vision dapat memberikan perhatian lebih kepada pelanggan apabila terjadi gangguan atau trouble dengan cara memberikan respon yang cepat dan tanggap,apabila tim teknisi corporate mengalami keterlambatan dalam mengatasi masalah atau gangguan yang terjadi maka pihak MNC Vision perlu memberikan jaminan seperti potongan biaya iuran bulanan atau pun jaminan lainnya yang sesuai dengan ketentuan yang telah ditetapkan oleh perusahaan. Selain itu juga, layanan preventive maintenance berupa kunjungan tim teknisi minimal 3 bulan sekali untuk melakukan pemeliharaan alat-alat MNC Vision dapat benar-benar dijadwalkan dengan baik, teratur dan tepat waktu, sehingga dapat meningkatkan kepercayaan pelanggan kepada layanan yang telah dijanjikan. Hal ini dilakukan agar dapat meyakinkan 
pelanggan dengan jaminan pelayanan yang memuaskan dengan didukung karyawan yang professional dalam melayani pelanggan. Hal ini diharapkan dapat membuat konsumen corporate menyukai pelayanan yang diberikan MNC Vision sehingga pada akhirnya konsumen akan menjadikan MNC Vision menjadi pilihan utamanya.

b. Bagi Peneliti Selanjutnya

Penelitian selanjutnya diharapkan menggunakan dimensi menurut para ahli lainnya agar nantinya diketahui variabel apa saja yang berpengaruh paling optimal terhadap keputusan pembelian seperti citra perusahaan, promosi penjualan dan harga Selain itu, penelitian selanjutnya diharapkan dapat menggunakan objek penelitian yang berbeda dengan ruang lingkup populasi yang lebih luas dan sampel yang lebih banyak sehingga memberikan hasil yang lebih baik.

Pada tahun 2019 sebelum terjadi wabah virus Covid-19 kondisi perusahaan MNC Vision masih berjalan dengan baik terutama pada jenis pelanggan corporate meskipun pada tahun 2019 mengalami penurunan yang cukup signifikan. Pada awal tahun 2020 dengan muncul nya wabah virus Covid- 19 mengakibatkan lumpuhnya perekonomian di Indonesia terutama pada sektor hospitality yang berpengaruh besar terhadap property corporate yang dilakukan penutupan sementara sesuai dengan himbauan pemerintan yang berdampak pada pemberhentian berlangganan dan keterlambatan pembayaran iuran bulanan TV berlangganan MNC Vision. Sehingga terjadinya ketidakstabilan pada perusahaan MNC Vision, diharapkan bagi peneliti selanjutnya agar dapat mengantisipasi hal-hal yang tidak terduga seperti adanya wabah virus Covid-19 ini di penelitian selanjutnya.

\section{REFERENSI}

Adyanto, B. C., DAN Santosa, S. B. (2018). "Pengaruh Kualitas Layanan, Brand Image, Harga dan Kepercayaan Produk Terhadap Keputusan Pembelian (Studi layanan E-commerce Berrybenka.com)". Diponegoro Journal of Management, Volume 7,(ISSN (Online): 23373792), Halaman 1-20.

Al-Ekam, J. M. E. (2016). "The Mediating Effect of Brand Trust on The Influence of Communication, Price, and Product Quality on Consumer Purchase Behaviour in a Less Developed Country". Malaysian Management Journal, Vol. 20, 87-97.

Alim, S. A., dkk (2018). "Pengaruh Persepsi Label Halal dan Kualitas Produk Terhadap Keputusan Pembelian Produk Fesyen Muslim (Survei pada Pelanggan Produk Zoya Muslim di Kota Malang)". Jurnal Administrasi Bisnis (JAB), Vol. 62.

Amron. (2018). "The Influence of Brand Image, Brand Trust, Product Quality, and Price on the Consumer's Buying Decision of MPV Cars". European Scientific Journal May, Vol. 14

Aryaty, D., dan Budiatmo, A. (2017). "Pengaruh Kualitas Produk dan Citra Merek (Brand 
Image) Terhadap Keputusan Pembelian Smartphone Samsung Galaxy Series J (Studi Kasus Pada Konsumen Samsung Galaxy Series J Di Kota Semarang)". Jurnal Universitas Diponegoro.

Darwanto. (2007). Televisi Sebagai Media Pendidikan. Pustaka Pelajar.

Dharma, N. P. S. A., dan Sukaatmadja, I. P. G. (2015). "Pengaruh Citra Merek, Kesadaran Merek dan Kualitas Produk Terhadap Keputusan Membeli Produk Apple". E-Jurnal Manajemen Unud, Vol. 4(ISSN: 2302 - 8912), 3228 - 3255.

Faruq, U. (2018). "Analisis Pengaruh Electronic Word of Mouth, Kualitas Pelayanan, Harga dan Citra Merek Terhadap Keputusan Pembelian Pada Situs E-Commerce (Studi pada Zalora Indonesia di Semarang)". Jurnal Universitas Diponegoro.

Febriani, R. R. (2018). "Pengaruh Brand Image dan Kualitas Layanan Terhadap Kepercayaan dan Keputusan Pembelian Pada Toko Online (Studi pada Konsumen OLX.co.id di Kota Semarang)". Jurnal Universitas Diponegoro.

Fure, F., Lapian, J., dan Taroreh, R. (2015). "Pengaruh Brand Image, Kualitas Produk dan Harga Terhadap Keputusan Pembelian Konsumen di J.Co Manado". Jurnal EMBA, Vol. $3(1), 367-377$.

Harjuno, P. (2018). "Pengaruh Kualitas Produk, Persepsi Harga, dan Citra Merek terhadap Keputusan Pembelian Motor Matic Honda Scoopy". Universitas Negeri Yogyakarta.

Hendro, C. R., dan Hidayat, W. (2018). "Pengaruh Kualitas Produk, Harga dan Citra Merek Terhadap Keputusan Pembelian Konsumen Handphone Merek Iphone Kota Semarang". Diponegoro Journal of Social and Politics, 1-15.

Isyanahapsari, S. (2016). "Pengaruh Periklanan dan Kualitas Pelayanan Terhadap Keputusan Pembelian Secara Online Pada Situs Belanja Online (Studi Kasus pada Pengguna Ecommerce Elevenia Di Kota Semarang)". Jurnal Universitas Diponegoro.

Jundi, M. S. (2016). "Analisis Pengaruh Kualitas Layanan, Citra Merek dan Kepercayaan Terhadap Keputusan Pembelian Melalui Nilai yang Dipersepsikan Sebagai Mediasi Pada Toko Online Lazada. co.id (Studi pada Konsumen Lazada.co.id Kota Semarang)". Jurnal Universitas Diponegoro.

Kotler, P., dan Armstrong, G. (2015). Marketing an Intoducing Prentice Hall (12th ed.). England: Pearson Education, Inc.

Kotler, P., dan Keller, K. L. (2009). Manajemen Pemasaran. Edisi 13 Jilid Satu. Jakarta: Erlangga.

Kotler, P., dan Keller, K. L. (2016). Marketing Management (15th ed.). Pearson Education, Inc. Kusumah, R. Z. (2016). "Analisis Pengaruh Kualitas Produk dan Kualitas Pelayanan Terhadap Keputusan Pembelian Pada Restoran Waroeng Taman Singosari di Semarang". Jurnal Universitas Diponegoro.

Monalisa, A. L., Suharyono, \& Sunarti. (2015). "Pengaruh Kualitas Produk Terhadap International Brand Image serta Dampaknya Terhadap Keputusan Pembelian (Studi pada Mahasiswa Pembeli dan Pengguna Laptop Lenovo di Fakultas Ilmu Administrasi Universitas Brawijaya)". Jurnal Administrasi Universitas Brawijaya, Vol. 28.

Parasuraman, A., dkk (1990). Delivering Quality Service: Balancing Customer Perception and Expectation. New York: The Free Press.

Permatasari, E. N. (2017). "Pengaruh Kualitas Pelayanan, Persepsi Harga dan Lokasi Terhadap Keputusan Pembelian Pada Pelanggan Minimarket (Studi Kasus Pada Pelanggan Minimarket Alfamart Tayu Wetan, Tayu, Pati, Jawa Tengah)". Jurnal Universitas Negeri Yogyakarta.

Pratama, D. W., dan Santoso, S. B. (2018). "Pengaruh Citra Merek, Kualitas Produk dan Harga Terhadap Keputusan Pembelian melalui Kepercayaan Konsumen pada Produk Stuck Original". Diponegoro Journal of Management, Vol. 7 (2)(ISSN (Online): 2337-3792), 111.

Pratiwi, D. E., Hidayat, W., dan Hermani, A. (2018). "Pengaruh Harga, Kualitas Produk dan 
Lokasi Terhadap Keputusan Pembelian (Studi Pada Pelanggan Mr. K Cafe Cabang Jl. Ki Mangunsarkoro 15 Semarang)". Jurnal Universitas Diponegoro.

Putri, D. A. (2017). "Hubungan Kualitas Produk Dengan Keputusan Pembelian Handphone Android Pada Mahasiswa Psikologi Universitas Medan Area". Jurnal Ekonomi Dan Kewirausahaan.

S, A. F., dan Suryoko, S. (2017). "Pengaruh Citra Merek, Kualitas Produk, dan Harga Terhadap Keputusan Pembelian Produk Tas dan Sepatu Charles \& Keith (Studi Kasus Konsumen Charles \& Keith Paragon Semarang)". Jurnal Universitas Diponegoro.

Sulistyorini, O. D. (2018). "Pengaruh Kualitas Produk, Variasi Produk, Kesesuaian Harga, Citra Merek, dan Kesadaran Merek Dalam Upaya Meningkatkan Keputusan Pembelian (Studi Kasus pada Strada Coffee Semarang)". Jurnal Universitas Diponegoro.

Sumpu, N., dan Tumbel, A. L. (2018). "Analisis Pengaruh Citra Merek dan Kualitas Produk Terhadap Keputusan Pembelian Smartphone Samsung (Studi Pada Mahasiswa Universitas Samratulangi Manado Angkatan 2016)". Jurnal EMBA, Vol. 6 (4)(ISSN 23031174), $2528-2537$.

Supriyadi, Fristin, Y., dan Indra, G. (2016). "Pengaruh Kualitas Produk dan Brand Image Terhadap Keputusan Pembelian". Jurnal Bisnis dan Manajemen, Vol. 3 (1).

Tugiso, I., Haryono, A. T., dan Minarsih, M. M. (2016). "Pengaruh Relationship Marketing, Keamanan, Kepercayaan dan Kualitas Pelayanan Terhadap Keputusan Pembelian Online Shop dan Loyalitas Konsumen Sebagai Variabel Intervening". Journal of Management, Volume 2.

Vatjanasaregagu, L., dan Thammathira, S. (2017). "The Impact Of Service Quality And Consumer Decision Factors On Brand Equity". International Business \& Economics Research Journal, Vol. 6 (3).

Wicaksana, B. S. (2018). "Analisis Pengaruh Kualitas Produk, Harga, Celebrity Endorser, dan Desain Produk Terhadap Keputusan Pembelian Sepeda Motor Yamaha Mio M3 di Kota Semarang". Jurnal Universitas Diponegoro. 